\title{
3-D simulation of posterior fossa reduction in Chiari I
}

\author{
Simulação em 3D da redução da fossa posterior no Chiari do tipo I \\ Yvens Barbosa Fernandes, 13 , Pedro Fábio Mendonça Perestrelo², Pedro Yoshito Noritomi², Roger Neves \\ Mathias ${ }^{3}$, Jorge Vicente Lopes da Silva ${ }^{2}$, Andrei Fernandes Joaquim ${ }^{1,3}$
}

\begin{abstract}
We proposed a 3D model to evaluate the role of platybasia and clivus length in the development of Chiari I (Cl). Using a computer aided design software, two DICOM files of a normal CT scan and MR were used to simulate different clivus lengths (CL) and also different basal angles (BA). The final posterior fossa volume (PFV) was obtained for each variation and the percentage of the volumetric change was acquired with the same method. The initial normal values of CL and BA were $35.65 \mathrm{~mm}$ and $112.66^{\circ}$ respectively, with a total PFV of 209 $\mathrm{ml}$. Ranging the CL from 34.65 to $29.65-24.65$ - 19.65, there was a PFV decrease of $0.47 \%-1.12 \%-1.69 \%$, respectively. Ranging the BA from $122.66^{\circ}$ to $127.66^{\circ}-142.66^{\circ}$, the PFV decreased $0.69 \%-3.23 \%$, respectively. Our model highlights the importance of the basal angle and clivus length to the development of $\mathrm{Cl}$.
\end{abstract}

Keywords: Chiari I; clivus length; platybasia; tonsillar herniation; 3D computational model.

\section{RESUMO}

No presente estudo, propusemos a criação de um modelo computacional em 3D com elaboração de software onde dois arquivos em formato DICOM com uma TC e RNM de crânio foram usados para simular diferentes mensurações na extensão do clivus (EC) e no ângulo basal (AB). 0 volume final da fossa posterior (VFP) foi obtido em cada variação, bem como a percentagem de volume alterada. 0 tamanho inicial da EC era de 35,65 mm e o do AB era de 112.66 , com um VFP de $209 \mathrm{ml}$. Variando a EC de 34,65 para 29,65 - 24.65 e 19.65, houve uma diminuição do VFP de $0.47 \%, 1.12 \%$ e 1.69\%, respectivamente. Variando o AB de 122,66 para $127,66^{\circ}$ e $142,66^{\circ}$, o VFP diminui para $0.69 \%$ e $3.23 \%$, respectivamente. Nosso modelo enfatiza a importância da patogênese do aumento do AB e do encurtamento do clivus no desenvolvimento do Chiari l.

Palaras-chave: Chiari I; extensão do clivus, platibasia; herniação tonsilar; modelo computacional em 3D.

Chiari I (CI) is one of the most common congenital craniocervical disorders and its diagnosed when there is tonsillar herniation into the foramen magnum of up to 3-5 $\mathrm{mm}^{1,2}$. The impaction of the tonsils at the level of the foramen magnum can lead to interruption of the cerebrospinal fluid flow and clinical symptoms, with upper cervical spine compression ${ }^{2,3,4}$. The incidence of $\mathrm{CI}$ in a general population is estimate in about $0.1-0.5 \%$, even though most of them are asymptomatic ${ }^{5,6}$.

One of the potential reasons for CI is decreased posterior fossa, secondary to shortness of the clivus and platybasia, commonly found in patients with this anomaly ${ }^{3,4,7}$. However, the role of loss of posterior fossa volume (PFV) secondary to clivus shortness and platybasia were not clearly measured yet. By this reason, in the current manuscript, we described and proposed a 3D computational model to simulate changes in the PFV using different clivus and basal angles lengths.

\section{METHODS}

A CT scan of a normal (without tonsillar herniation) control male adult subject was used as a model. The images were saved in a Digital Imaging and Communications in Medicine (DICOM) format and were treated using the

${ }^{1}$ Hospital Municipal Mário Gatti, Departamento de Neurocirurgia, Campinas SP, Brasil;

${ }^{2}$ Centro de Tecnologia de Informação Renato Archer, Three Dimensional Technologies Division, Campinas SP, Brasil;

${ }^{3}$ Universidade Estadual de Campinas, Departamento de Neurologia, Campinas SP, Brasil.

Correspondence: Andrei F. Joaquim; Departamento de Neurologia, Univesidade Estadual de Campinas; Cidade Universitária Zeferino Vaz; $13090-610$

Campinas SP, Brasi; E-mail: andjoaquim@yahoo.com

Conflict of interest: There is no conflict of interest to declare.

Received 27 October 2015; Received in final form 08 February 2016; Accepted 24 February 2016. 
software InVesalius ${ }^{\bullet}$, to remove imperfections and unnecessary tissues for volume evaluation. After that, the files were exported to the software Rhinoceros ${ }^{\oplus}$, a computer aided design (CAD) program used to formulate the computational model. We could reproduce, in a virtual environment, the changes necessary for estimating the PFV. Two basic measurements were used as variables:

1) Basal angle - formed by a line extending from the nasion to the posterior tubercullum sellae and then another line from the posterior tubercullum sellae to the basion and

2) Clivus length - calculated from the distance in millimeters (mm) from the posterior tubercullum sellae to the basion.

Finally, successive measurements of the PFV were estimated based on changing these two variables.

\section{RESULTS}

The initial basal angle measured was $112.66^{\circ}$ and the clivus length was $34.65 \mathrm{~mm}$, with an initial PFV of $209 \mathrm{ml}$. In Table, we reported the PFV calculated in three different situations:

- decreasing the clivus length (5 $\mathrm{mm}$ progressively),

- $\quad$ increasing the basal angle ( $5^{\circ}$ progressively) and,

- a combination of decreasing clivus lengths and concomitant increasing the basal angles.

Figures 1, 2, 3 and 4 illustrate our computational model for calculating posterior fossa volume.

\section{DISCUSSION}

The real cause of CI remains elusive despite more than 100 years since its initial description by Hans Chiari ${ }^{8,9}$. Recently, we proposed a new hypothesis to explain the origin of $\mathrm{CI}$ based on the evolution of the skull base of the Homo clade in the Pleistocene Epoch (beginning about 2,6 million years ago) ${ }^{7}$. It is well known by anthropological data that the basal angle has been constantly decreasing during hominins evolution to give extra volume to the remarkable brain size increase (at least threefold in the last 4 million years $)^{7}$. In the most primitive hominins, such as in the Homo erectus, the basal angle was estimated to be much higher than, for instance, in Homo sapiens, suggesting its importance to the modern shape of the human skull base ${ }^{7,10,11}$.

In patients with $\mathrm{CI}$ a higher incidence of platybasia and shortness of clivus has been described by some authors ${ }^{2,12,13}$. Karagöz et al. ${ }^{13}$ performed a craniometrical study in 22 patients with $\mathrm{CI}$, comparing them with 21 normal subjects as a control group. They reported that, in CI group, the depth of the posterior fossa and the length of the clivus were shorter than in normal subjects ( $p<0.001$ and $p=0.007$, respectively). The ratios of the depth of the posterior fossa to the height of the supratentorial region were also significantly smaller in the Chiari group compared with controls $(\mathrm{p}<0.001)$ and patients with CI had a tendency for platybasia. They concluded that their findings strongly supported the existence of underdevelopment of the posterior fossa and the occipital bone in patients with CI.

Table. Posterior fossa volume according to changing in the clivus length and the basal angle. A total of 19 combinations were obtained.

\begin{tabular}{|c|c|c|c|c|}
\hline & \multicolumn{2}{|c|}{ Parameters } & Volume $\left(\mathrm{cm}^{3}\right)$ & Volume (\%) \\
\hline Original Craniometrical values & \multicolumn{2}{|c|}{$122.66^{\circ}$ e $34.65 \mathrm{~mm}$} & 209.650 & 100 \\
\hline \multirow{3}{*}{ Clivus Shortness } & \multicolumn{2}{|c|}{$34.65 \mathrm{~mm}$ to $19.65 \mathrm{~mm}$} & 206.118 & 98.315 \\
\hline & \multicolumn{2}{|c|}{$34.65 \mathrm{~mm}$ to $24.65 \mathrm{~mm}$} & 207.308 & 98.883 \\
\hline & \multicolumn{2}{|c|}{$34.65 \mathrm{~mm}$ to $29.65 \mathrm{~mm}$} & 208.658 & 99.527 \\
\hline \multirow{4}{*}{ Increasing basal angle } & \multicolumn{2}{|c|}{$122.66^{\circ}$ to $127.66^{\circ}$} & 208.204 & 99.310 \\
\hline & \multicolumn{2}{|c|}{$122.66^{\circ}$ to $132.66^{\circ}$} & 207.074 & 98.771 \\
\hline & \multicolumn{2}{|c|}{$122.66^{\circ}$ to $137.66^{\circ}$} & 205.168 & 97.862 \\
\hline & \multicolumn{2}{|c|}{$122.66^{\circ}$ to $142.66^{\circ}$} & 202.884 & 96.773 \\
\hline \multirow{12}{*}{$\begin{array}{l}\text { Shortness of clivus and } \\
\text { Increasing the basal angle }\end{array}$} & $34.65 \mathrm{~mm}$ to $19.65 \mathrm{~mm}$ & $122.66^{\circ}$ to $127.66^{\circ}$ & 205.056 & 97.809 \\
\hline & $34.65 \mathrm{~mm}$ to $19.65 \mathrm{~mm}$ & $122.66^{\circ}$ to $132.66^{\circ}$ & 203.206 & 96.926 \\
\hline & $34.65 \mathrm{~mm}$ to $19.65 \mathrm{~mm}$ & $122.66^{\circ}$ to $137.66^{\circ}$ & 202.210 & 96.451 \\
\hline & $34.65 \mathrm{~mm}$ to $19.65 \mathrm{~mm}$ & $122.66^{\circ}$ to $142.66^{\circ}$ & 201.164 & 95.952 \\
\hline & $34.65 \mathrm{~mm}$ to $24.65 \mathrm{~mm}$ & $122.66^{\circ}$ to $127.66^{\circ}$ & 205,164 & 97.860 \\
\hline & $34.65 \mathrm{~mm}$ to $24.65 \mathrm{~mm}$ & $122.66^{\circ}$ to $132.66^{\circ}$ & 204.298 & 97.447 \\
\hline & $34.65 \mathrm{~mm}$ to $24.65 \mathrm{~mm}$ & $122.66^{\circ}$ to $137.66^{\circ}$ & 203.190 & 96.919 \\
\hline & $34.65 \mathrm{~mm}$ to $24.65 \mathrm{~mm}$ & $122.66^{\circ}$ to $142.66^{\circ}$ & 202.232 & 96.462 \\
\hline & $34.65 \mathrm{~mm}$ to $29.65 \mathrm{~mm}$ & $122.66^{\circ}$ to $127.66^{\circ}$ & 206.364 & 98.433 \\
\hline & $34.65 \mathrm{~mm}$ to $29.65 \mathrm{~mm}$ & $122.66^{\circ}$ to $132.66^{\circ}$ & 204.608 & 97.595 \\
\hline & $34.65 \mathrm{~mm}$ to $29.65 \mathrm{~mm}$ & $122.66^{\circ}$ to $137.66^{\circ}$ & 202.958 & 96.808 \\
\hline & $34.65 \mathrm{~mm}$ to $29.65 \mathrm{~mm}$ & $122.66^{\circ}$ to $142.66^{\circ}$ & 201.580 & 96.51 \\
\hline
\end{tabular}




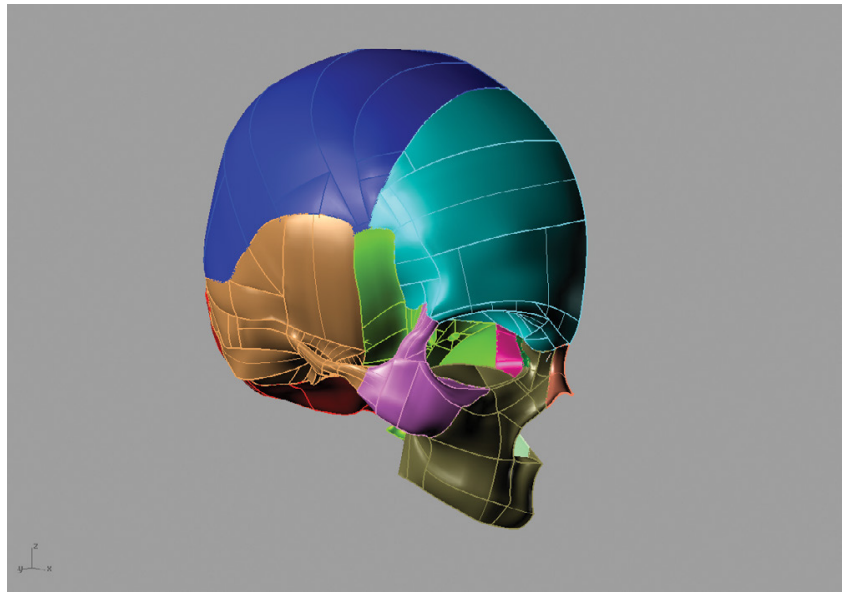

Figure 1. The virtual model created based on the normal subject model and his DICOM images of the CT scan .

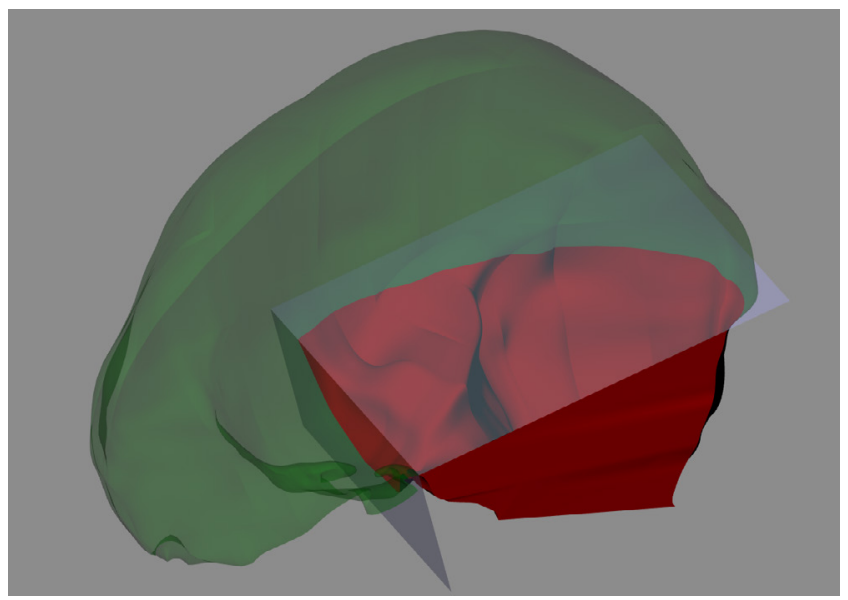

Figure 3. Computational model with the posterior fossa volume (red) and the supratentorial content (green).

Similar results were reported by Heiss et al., who compared the craniometrical findings of $48 \mathrm{CI}$ patients with 18 healthy volunteers as a control group ${ }^{12}$. Patients with $\mathrm{C}$ I had a smaller clivus length (38.6 $\pm 3.4 \mathrm{~mm}$ versus $43.2 \pm 3.5 \mathrm{~mm}$ in the control group; $\mathrm{p}<0.001$ ) and also a smaller basiocciput (19.7 \pm 3.3 versus $26.3 \pm 4.4 \mathrm{~mm}$ in the control group; $\mathrm{p}<0.0001$ ). Considering this evidences, we proposed a 3D computational model to measure the loss of volume secondary to a progressive increase in the basal angle and also shortening the clivus to estimate the changes in the final PFV.

Our obtained data suggested that the PFV is affected by changing both variables leading to tonsillar herniation and clinical symptoms. Curiously, in our computational model, we demonstrated that the herniated estimated tonsillar volume was quite similar to the amount of decreased PFV.

\section{Limitations}

Our study is limited by a single model of a normal subject and also for not considering all complex geometry of

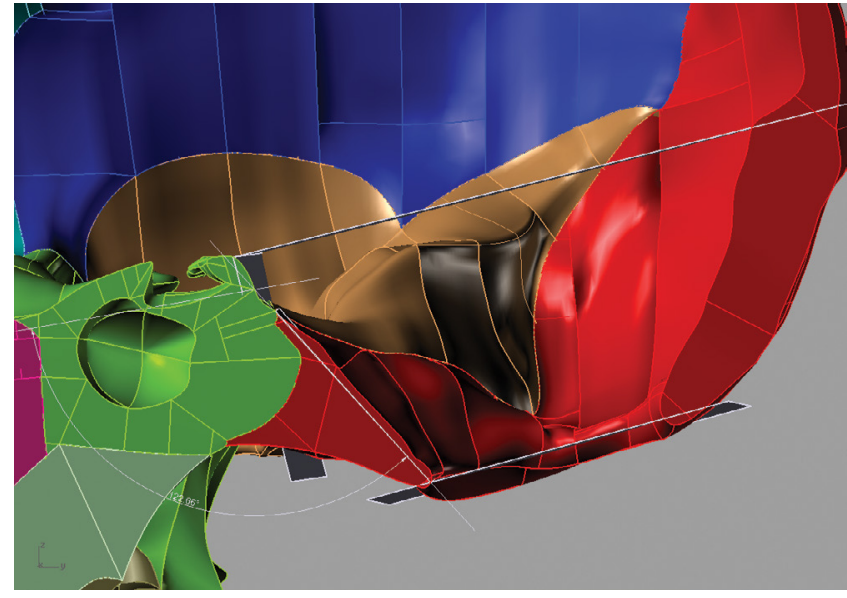

Figure 2. The virtual model created for measurement of the posterior fossa volume based on the normal subject model and his DICOM images of a CT scan.

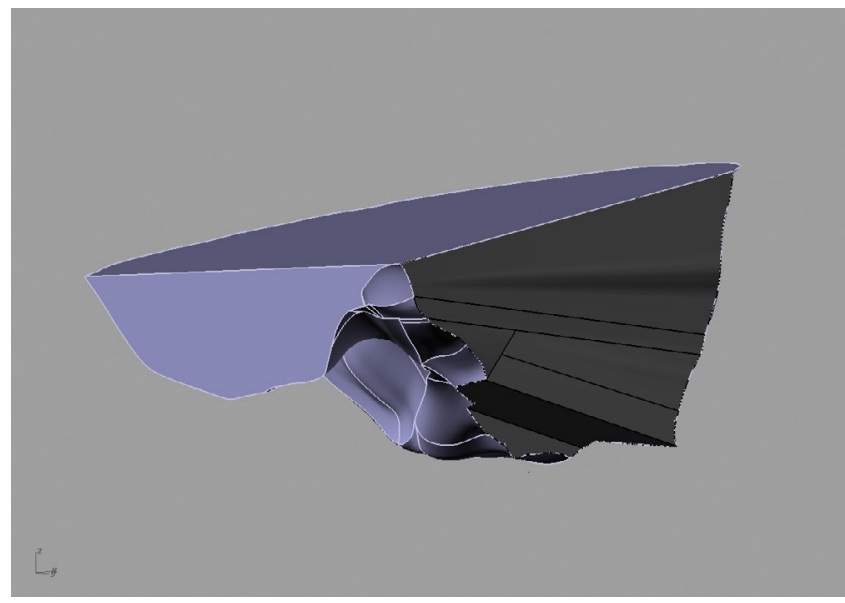

Figure 4. Computational rendering of the posterior fossa.

the posterior fossa, since just two parameters were changed. However, our preliminary computational model was successfully designed for initial volumetric evaluation of the posterior fossa, potentially opening perspectives for further refinements and future studies, such as a genetic link between ancient skulls and the incidence of tonsillar herniation secondary to clivus shortness and platybasia.

In conclusion we proposed a 3D computational model that was able to predict the final PFV after changing the basal angle and clivus length. Our model seems to highlight the importance of the basal angle and clivus length to the development of the CI. Tonsillar herniation may be explained by slight changes on both variables. Further studies addressing the role of clivus and basal angle might be warranted to better understand the influence of anthropological evolution and anatomical changes involved in the etiology of CI.

Finally, we believe that Chiari is not a malformation and this term should be avoided. CI might be seen as an imprint of the long evolutionary journey of the genus Homo on earth. 
1. Guo F, Wang M, Long J, Wang H, Sun H, Yang B et al. Surgical management of Chiari malformation: analysis of 128 cases. Pediatr Neurosurg. 2007;43(5):375-81. doi:10.1097/00013414-200306000-00005

2. Joaquim AF, Fernandes YB, Mathias RN, Batista UC, Ghizoni E, Tedeschi $\mathrm{H}$ et al. Incidence of Basilar invagination in patients with Tonsillar herniation: a case control craniometrical study. Arq Neuropsiquiatr. 2014;72(9):706-11. doi:10.1590/0004-282X20140113

3. Joaquim AF, Ghizoni E, Giacomini LA, Tedeschi H, Patel AA. Basilar invagination: Surgical results. J Craniovertebr Junction Spine. 2014;5(2):78-84. doi:10.4103/0974-8237.139202

4. Goel A. Basilar invagination, Chiari malformation, syringomyelia: a review. Neurol India. 2009;57(3):235-46. doi:10.4103/0028-3886.53260

5. Speer MC, Enterline DS, Mehltretter L, Hammock P, Joseph J, Dickerson $\mathrm{M}$ et al. Chiari type I malformation with or without syringomyelia: prevalence and genetics. J Genet Couns. 2003;12(4):297-311. doi:10.1023/A:1023948921381

6. Meadows J, Kraut M, Guarnieri M, Haroun RI, Carson BS. Asymptomatic Chiari Type I malformations identified on magnetic resonance imaging. J Neurosurg. 2000;92(6):920-6. doi:10.3171/jns.2000.92.6.0920
7. Fernandes YB, Ramina R, Campos-Herrera CR, Borges G. Evolutionary hypothesis for Chiari type I malformation. Med Hypotheses. 2013;81(4):715-9. doi:10.1016/j.mehy.2013.07.035

8. Chiari H. Über Veränderungen des Kleinhirns infolge von Hydrocephalie des Grosshirns. Dtsch med Wschr. 1891;17:1172-75.

9. Chiari H. Über Veränderungen des Kleinhirns, des Pons und der Medulla Oblongata in Folge von congenitaler Hydrocephalie des Grosshirns. Dtsch Akd Wissensch. 1895;63:71-125.

10. Lieberman DE, Ross CF, Ravosa MJ. The primate cranial base: ontogeny, function and integration. Am J Phys Anthropol Suppl 2000;31:117-69.

11. Lieberman DE. Sphenoid shortening and the evolution of modern human cranial shape. Nature. 1998; 393:158-62. doi:10.1038/30227

12. Heiss JD, Suffredini G, Bakhtian KD, Sarntinoranont M, Oldfield EH. Normalization of hindbrain morphology after decompression of Chiari malformation Type I. J Neurosurg. 2012;117(5):942-6. doi:10.3171/2012.8.JNS111476

13. Karagöz, F, Izgi, N, Kapíjcíjoğlu Sencer S. Morphometric measurements of the cranium in patients with Chiari Type I malformation and comparison with the normal population. Acta Neurochir (Wien). 2002;144(2):165-71. doi:10.1007/s007010200020 